Short communication

\title{
Selection of grapevine leaf varieties for culinary process based on phytochemical composition and antioxidant properties
}

\author{
Adriano Lima ${ }^{\mathrm{a}, \mathrm{b}}$, Albino Bento ${ }^{\mathrm{c}}$, Ilton Baraldi ${ }^{\mathrm{b}}$, Ricardo Malheiro ${ }^{\mathrm{a}, *}$ \\ ${ }^{a}$ School of Agriculture, Polytechnic Institute of Bragança, Campus de Santa Apolónia, 5300-253 Bragança, Portugal \\ ${ }^{\mathrm{b}}$ Universidade Tecnológica Federal do Paraná, Campus Medianeira, Avenida Brasil, 4232, Bairro Independência, CEP 85884-000 Medianeira, Paraná, Brazil \\ ${ }^{\mathrm{c}}$ Mountain Research Centre (CIMO)/School of Agriculture, Polytechnic Institute of Bragança, Campus de Santa Apolónia, 5300-253 Bragança, Portugal
}

\section{A R T I C L E I N F O}

\section{Article history:}

Received 4 February 2016

Received in revised form 22 May 2016

Accepted 30 May 2016

Available online 31 May 2016

\section{Keywords:}

Vitis vinifera $\mathrm{L}$.

Grapevine leaves

Variety

Antioxidant

Phytochemicals

\begin{abstract}
A B S T R A C T
Grapevine leaves are an abundant sub-product of vineyards which is devalued in many regions. The objective of this work is to study the antioxidant activity and phytochemical composition of ten grapevine leaf varieties (four red varieties: Tinta Amarela, Tinta Roriz, Touriga Franca, and Touriga Nacional; and six white varieties: Côdega do Larinho, Fernão Pires, Gouveio, Malvasia Fina, Rabigato, and Viosinho) to select varieties to be used as food ingredients.

White grapevine leaves revealed higher antioxidant potential. Malvasia Fina reported better antioxidant properties contrasting with Touriga Franca. Phenolic content varied between 112 and $150 \mathrm{mg} \mathrm{GAE} \mathrm{g}^{-1}$ of extract (gallic acid equivalents), hydroxycinnamic acid derivatives and flavonols varied between 76 and $108 \mathrm{mg} \mathrm{CAE} \mathrm{g}^{-1}$ of extract (caffeic acid equivalents) and 39 and $54 \mathrm{mg} \mathrm{QE} \mathrm{g}^{-1}$ of extract (quercetin equivalents).

Malvasia Fina is a good candidate for culinary treatment due to its antioxidant properties and composition in bioactive compounds.
\end{abstract}

(c) 2016 Elsevier Ltd. All rights reserved.

\section{Introduction}

Vitis vinifera $\mathrm{L}$. is one of the most widely cultivated crop worldwide, with an estimated grape production over 77 million tonnes in 2013 (FAOSTAT, 2015). The wine making industry and the grapevine itself lead to the production of high volumes of by-products. One of those by-products is the grapevine leaves. Grapevine leaves are considered a delicacy in many countries of the Mediterranean Basin (Harb, Alseekh, Tohge, \& Fernie, 2015), while in others are considered a waste and strategies to valorize them are inexistent. According to recent studies (Andelković, Radovanović, Andelković, \& Radovanović, 2015; Farhadi, Esmaeilzadeh, Hatami, Forough, \& Molaie, 2016; Katalinić et al., 2013), grapevine leaves are an excellent source of bioactive compounds, mainly phenolic compounds, that exert several beneficial properties. Grapevine leaves, according to Aguilar et al. (2015), are good natural products for the treatment of a series of health problems, like hypertension, diarrhea, hemorrhage, inflammatory disorder, hypoglycemia and chronic venous insufficiency. Therefore, the inclusion of grapevine leaves in the human diet is a good strategy to valorize this vine by-product, increasing as well the intake of important minor

\footnotetext{
* Corresponding author.

E-mail address: rmalheiro@ipb.pt (R. Malheiro).
}

components (Monagas, Hernández-Ledesma, Gómez-Cordovés, \& Bartolomé, 2006), with nutritional and healthy properties.

Grapevine leaves inclusion in human diet has to overcome culinary processes, since in their raw form they are not edible. Therefore, in an initial phase, the study of different grapevine leaf varieties is essential to identify those with higher properties and phytochemicals, to be then submitted to culinary processes, in order to give to consumers highest levels bioactive components. Therefore, in the present study, the main objective was to perform a screening on the antioxidant properties and phytochemical composition of ten grapevine leaves from white and red varieties, in order to select the most suitable varieties to be submitted for culinary processes.

\section{Material and methods}

\subsection{Plant material}

The selection of grapevine leaf varieties for culinary process was based in ten varieties, being the most cultivated in the Planalto Mirandês (Trás-os-Montes region, in the Northeast region of Portugal).

Six white grapevine leaf (Côdega do Larinho, Fernão Pires, Gouveio, Malvasia Fina, Rabigato, and Viosinho) and four red grapevine 
leaf varieties (Tinta Amarela, Tinta Roriz, Touriga Franca, and Touriga Nacional) were selected, as illustrated in Fig. 1. The ten varieties were collected within the same edaphoclimatic conditions and agronomic practices. The harvest was made in July 2015 and three independent samples (approximately $500 \mathrm{~g}$ of leaves) per variety were collected. Once in laboratory, leaves were visually inspected and those with signs of pests and diseases as well as mechanical damages or with birds excrements were rejected for analysis, being all the debris removed and leaves cleaned when necessary with distilled water. Dust was removed with a slightly humidified scientific paper, while persistent and dried earth was removed with a jet of distilled water to avoid mechanical damages and cells disruption in the leaves. All samples were then frozen.

\subsection{Samples preparation and extraction conditions}

All samples were freeze-dried and then grinded. The aqueous extraction was performed according to Malheiro et al. (2012) with small modifications as briefly described: $5 \mathrm{~g}$ of freeze-dried leaves were extracted with $250 \mathrm{~mL}$ boiling water during $45 \mathrm{~min}$, and then the extract was filtered through Whatman No. 4 paper. The aqueous extract was frozen, freeze-dried and dissolved in water to a final concentration of $50 \mathrm{mg} \mathrm{mL}^{-1}$. For each parameter assessed in this study, per extract, two replicates were performed.

\subsection{Antioxidant activity determination}

\subsubsection{Scavenging effect on DPPH radicals}

The capacity to scavenge the free radical 2,2-diphenyl-1picrylhydrazyl (DPPH) was monitored according to the method of Hatano, Kagawa, Yasuhara, and Okuda (1988). The extract solution $(0.3 \mathrm{~mL})$ was mixed with $2.7 \mathrm{~mL}$ of a methanol solution containing DPPH radicals $\left(6 \times 10^{-5} \mathrm{~mol} / \mathrm{L}\right)$. The mixture was shaken vigorously and left to stand for $60 \mathrm{~min}$ at room temperature in the dark (until stable absorbance values were obtained). The reduction of the DPPH radical was measured by continuous monitoring of the absorption decrease at $517 \mathrm{~nm}$ (Genesys 10UV, Thermo Electron Corporation). DPPH scavenging effect was calculated as the percentage of DPPH discoloration using the following equation: \% scavenging effect $=[(\mathrm{ADPPH}-\mathrm{AS}) / \mathrm{ADPPH}] \times 100$, where AS is the absorbance of the solution when the sample extract has been added, and ADPPH is the absorbance of the DPPH solution. The extract concentration providing $50 \%$ inhibition $\left(\mathrm{EC}_{50}\right)$ was calculated from the graph of scavenging effect percentage against extract concentration in the solution.

\subsubsection{Scavenging effect on ABTS radicals}

The ABTS method was applied according to that described by Karaçelil et al. (2015), based on the capacity of a sample to inhibit the ABTS radical. The ABTS radical was generated by chemical reaction with potassium persulfate $\left(\mathrm{K}_{2} \mathrm{~S}_{2} \mathrm{O}_{8}\right)$. To $25 \mathrm{~mL}$ of ABTS ( $7 \mathrm{mmol} / \mathrm{L})$ were added $440 \mathrm{~mL}$ of $\mathrm{K}_{2} \mathrm{~S}_{2} \mathrm{O}_{8}(140 \mathrm{mmol} / \mathrm{L})$, being the solution kept in darkness during $12-16 \mathrm{~h}$ at room temperature in order to form the radical. An accurate volume of the previous solution was diluted in ethanol until an absorbance of $0.70 \pm 0.02$ at $\lambda=734 \mathrm{~nm}$ (Genesys 10UV, Thermo Electron Corporation). Once the radical was formed $2 \mathrm{~mL}$ of the ABTS radical solution were mixed with $100 \mathrm{~mL}$ of aqueous extract of grapevine leaf at different concentrations (0.01-2 $\mathrm{mg} \mathrm{mL}^{-1}$ ) and the absorbance measured at $\lambda=734 \mathrm{~nm}$. The ABTS scavenging effect and $\mathrm{EC}_{50}$ values were calculated according to the previously mentioned for the DPPH method.

\subsubsection{Reducing power}

The reducing power was determined according to a described procedure (Berker, Güçlü, Tor, \& Apak, 2007). The extract solution ( $1 \mathrm{~mL}$ from 0.1 to $2 \mathrm{mg} \mathrm{mL}^{-1}$ ) was mixed with $2.5 \mathrm{~mL}$ of $200 \mathrm{mmol} /$ L sodium phosphate buffer ( $\mathrm{pH} 6.6$ ) and $2.5 \mathrm{~mL}$ of $1 \%$ potassium ferricyanide. The mixture was incubated at $50{ }^{\circ} \mathrm{C}$ for $20 \mathrm{~min}$. After cooling, $2.5 \mathrm{~mL}$ of $10 \%$ trichloroacetic acid (w/v) were added and the mixture was centrifuged at $1000 \mathrm{rpm}$ for $8 \mathrm{~min}$ (Centorion K24OR-2003 refrigerated centrifuge). The upper layer $(2.5 \mathrm{~mL})$ was mixed with $2.5 \mathrm{~mL}$ of deionised water and $0.5 \mathrm{~mL}$ of $0.1 \%$ ferric chloride, and the absorbance was measured spectrophotometrically at $700 \mathrm{~nm}$ (higher absorbance readings indicate higher reducing power). Extract concentration providing 0.5 of absorbance $\left(E_{50}\right)$ was calculated from the graph of absorbance at $700 \mathrm{~nm}$ (Genesys 10UV, Thermo Electron Corporation) against extract concentration in the solution.

\subsubsection{Total reducing capacity}

Total reducing capacity was performed according to Singleton and Rossi (1965), with some modifications. Thus, $1 \mathrm{~mL}$ (at $0.5 \mathrm{mg} \mathrm{mL}^{-1}$ ) of the extract solution was mixed with $1 \mathrm{~mL}$ of Foli n-Ciocalteau's phenol reagent. The mixture was shaken vigorously and left to stand for $3 \mathrm{~min}$. After that, $1 \mathrm{~mL}$ of a saturated solution of sodium carbonate was added and the total volume was adjusted to $10 \mathrm{~mL}$ with distilled water. The reaction was kept in the dark for $90 \mathrm{~min}$, after that the absorbance was read at $725 \mathrm{~nm}$ in a Thermo Electron Corporation Genesys 10UV spectrometer. Gallic acid was used as standard, being the results expressed in $\mathrm{mg}$ of gallic acid equivalents (GAE) $\mathrm{g}^{-1}$ of extract.

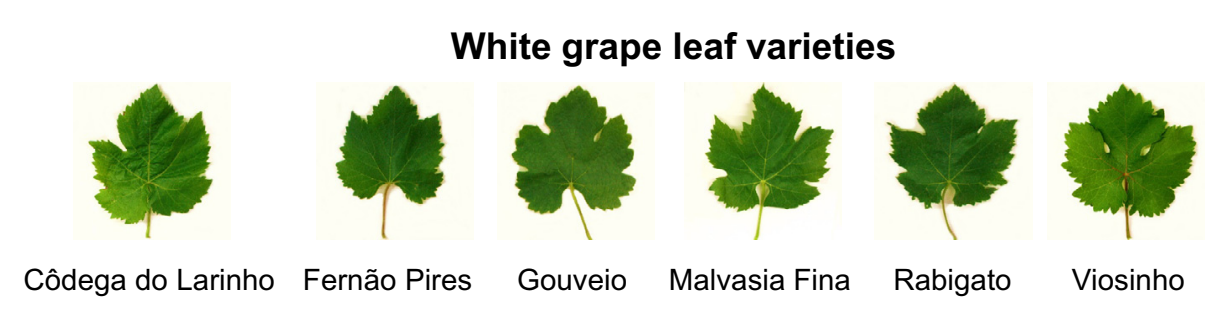

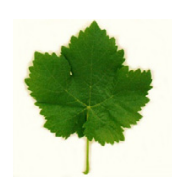

Tinta Amarela

\section{Red grape leaf varieties}
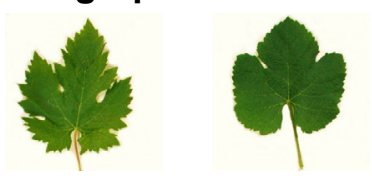

Tinta Roriz

Touriga Franca

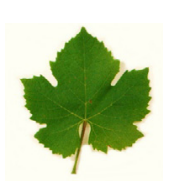

Touriga Nacional

Fig. 1. White and red grapevine leaf varieties in study. 


\subsection{Determination of different groups of phenolic compounds}

The determination of total phenols content, hydroxycinnamic acid derivatives and flavonols was performed according to the methodology described by Boulanoular, Abdelaziz, Aazza, Gago, and Miguel (2013). One milliliter $\left(0.5 \mathrm{mg} \mathrm{mL}^{-1}\right.$ of extract) was diluted with $1 \mathrm{~mL}$ of aqueous ethanol (95\% v/v) containing $0.1 \%$ of hydrochloric acid and $8 \mathrm{~mL}$ of $2 \%$ hydrochloric acid. The absorbance was measured at $280 \mathrm{~nm}$ to determine total phenols, at $320 \mathrm{~nm}$ to determine hydroxycinnamic acid derivatives, and at $360 \mathrm{~nm}$ to determine flavonols content (Genesys 10UV, Thermo Electron Corporation). The results were expressed as gallic acid equivalents (GAE) $\mathrm{g}^{-1}$ of extract for total phenols, caffeic acid equivalents (CAE) $\mathrm{g}^{-1}$ of extract for hydroxycinnamic acid derivatives, and quercetin $(\mathrm{QE}) \mathrm{g}^{-1}$ of extract for flavonols.

\subsection{Statistical analysis}

\subsubsection{Analysis of variance}

An analysis of variance (ANOVA) with Type III sums of squares was performed using the GLM (General Linear Model procedure) of the SPSS software, version 22.0 (IBM Corporation, New York, U.S. A.). The fulfilment of the ANOVA requirements, namely the normal distribution of the residuals and the homogeneity of variance, were evaluated by means of the Kolmogorov-Smirnov with Lilliefors correction (if $n>50$ ) or the Shapiro-Wilk's test (if $n<50$ ), and the Levene's tests, respectively. All dependent variables were analysed using a one-way ANOVA with or without Welch correction, depending if the requirement of the homogeneity of variances was fulfilled or not. The main factor studied was the effect of variety in the antioxidant activity and composition of the aqueous extracts of the ten grapevine leaf varieties. If a statistical significant effect was found, means were compared using Tukey's honestly significant difference multiple comparison test or Dunnett T3 test also depending if equal variances could be assumed or not. All statistical tests were performed at a 5\% significance level.

\subsubsection{Principal component analysis}

Principal components analysis (PCA) was applied for reducing the number of variables in the antioxidant activity and phytochemicals composition of grapevine leaf varieties to a smaller number of new derived variables (principal component or factors) that adequately summarize the original information. Overall 7 variables corresponding to the antioxidant activity and phenolic composition of the grapevine leaf varieties were used in PCA. PCA was performed by using SPSS software, version 22.0 (IBM Corporation, New York, U.S.A.).

\section{Results and discussion}

\subsection{Antioxidant activity}

A general observation was depicted from the antioxidant assays: white grapevine leaf varieties display higher antioxidant properties than red varieties (Table 1). In the DPPH assay white varieties display a general $\mathrm{EC}_{50}$ value of $0.175 \mathrm{mg} \mathrm{mL}^{-1}$, while red grapevine leaf varieties reported $0.213 \mathrm{mg} \mathrm{mL}^{-1}$. Among the 10 varieties studied, leaves from Rabigato reported lower $\mathrm{EC}_{50}$ value, corresponding higher antioxidant activity, with $0.133 \mathrm{mg} \mathrm{mL}^{-1}$, significantly higher comparatively to the four red grapevine leaf varieties studied $(P<0.001)$. In the other hand Tinta Roriz was the variety with lower capacity to scavenge the DPPH radicals, with an $\mathrm{EC}_{50}$ value of $0.234 \mathrm{mg} \mathrm{mL}^{-1}$ (Table 1 ). In the other anti-radical assay, ABTS, white varieties reported a mean $\mathrm{EC}_{50}$ value of $0.311 \mathrm{mg} \mathrm{mL}^{-1}$ while red varieties reported an $\mathrm{EC}_{50}$ value of $0.362 \mathrm{mg} \mathrm{mL}^{-1}$. Malvasia Fina, a white variety reported higher antioxidant capacity $\left(\mathrm{EC}_{50}\right.$ value $\left.=0.258 \mathrm{mg} \mathrm{mL}^{-1}\right)$, and Touriga Franca lower antioxidant activity $\left(0.402 \mathrm{mg} \mathrm{mL}^{-1}\right)$ (Table 1), with significant differences between these two varieties $(P<0.001)$. In fact Malvasia Fina reported significant higher $\mathrm{EC}_{50}$ values in ABTS method comparatively to the four red varieties studied (Table $1 ; P<0.001$ ).

In the reducing power, white varieties reported a general $\mathrm{EC}_{50}$ value of $0.421 \mathrm{mg} \mathrm{mL}^{-1}$, while red varieties presented an $\mathrm{EC}_{50}$ value of $0.466 \mathrm{mg} \mathrm{mL}^{-1}$. Among the varieties with higher reducing power was again Malvasia Fina $\left(\mathrm{EC}_{50}\right.$ value $=0.371 \mathrm{mg} \mathrm{mL}^{-1}$ ). This variety reported a significantly higher reducing power comparing to Tinta Amarela and Touriga Franca (red varieties) $(P<0.001)$. Touriga Franca was the variety with lowest reducing power $\left(\mathrm{EC}_{50}\right.$ value $=0.534 \mathrm{mg} \mathrm{mL}^{-1}$ ) (Table 1$)$.

As generally observed until now, total reducing capacity (TRC) was again greater in the white grapevine leaf varieties with an overall result of $99.4 \mathrm{mg} \mathrm{GAE} \mathrm{g}^{-1}$, while red varieties reported a general TRC of $85.6 \mathrm{mg} \mathrm{GAE} \mathrm{g}^{-1}$. Malvasia Fina reported higher TRC with $115 \mathrm{mg} \mathrm{GAE} \mathrm{g}^{-1}$, and Touriga Franca reported lower TRC with $72.5 \mathrm{mg} \mathrm{GAE} \mathrm{g}^{-1}$. The TRC reported by Malvasia Fina is in fact significantly higher $(P<0.001)$ than Gouveio and Viosinho (white varieties) and Tinta Roriz and Touriga Franca (Table 1).

The main observation taken from the antioxidant activity was that white varieties are more antioxidant than red ones, as reported in other studies (Fernandes et al., 2013). Grapevine leaves antioxidant properties are affected by several factors, like the variety, the cultivation region, the edaphoclimatic conditions, the agricultural practices and harvest season (Katalinić et al., 2009). In our study, the most important factor is the variety, since leaves were all from the same region, collected in the same day, and cultivated

Table 1

Extraction yield, antioxidant activity and total reducing capacity (TRC) of aqueous extracts of grapevine leaf varieties ( $\mathrm{n}=3$; mean \pm standard deviation).

\begin{tabular}{|c|c|c|c|c|c|c|}
\hline & Varieties & Extraction yield (\%) & $\mathrm{DPPH}\left(\mathrm{mg} \mathrm{mL}^{-1}\right)^{1}$ & $\operatorname{ABTS}\left(\mathrm{mg} \mathrm{mL}^{-1}\right)^{1}$ & Reducing power $\left(\mathrm{mg} \mathrm{mL}^{-1}\right)^{2}$ & TRC (mg AG $\left.\mathrm{g}^{-1}\right)$ \\
\hline \multirow[t]{6}{*}{ White } & Códega do Larinho & $29.8 \pm 0.77 \mathrm{a}-\mathrm{c}$ & $0.161 \pm 0.026 \mathrm{a}, \mathrm{b}$ & $0.297 \pm 0.046 \mathrm{a}, \mathrm{c}$ & $0.385 \pm 0.034 \mathrm{a}$ & $98.6 \pm 16.5 \mathrm{~b}-\mathrm{d}$ \\
\hline & Fernão Pires & $34.6 \pm 9.21 \mathrm{a}-\mathrm{c}$ & $0.178 \pm 0.030 \mathrm{c}-\mathrm{d}$ & $0.304 \pm 0.039 \mathrm{a}, \mathrm{c}$ & $0.413 \pm 0.031 \mathrm{a}, \mathrm{b}$ & $107 \pm 26.8 \mathrm{c}, \mathrm{d}$ \\
\hline & Gouveio & $29.8 \pm 1.19 a-c$ & $0.214 \pm 0.038 \mathrm{~d}, \mathrm{e}$ & $0.345 \pm 0.017 \mathrm{c}-\mathrm{e}$ & $0.506 \pm 0.040 \mathrm{~d}, \mathrm{e}$ & $82.0 \pm 11.5$ a,b \\
\hline & Malvasia Fina & $26.6 \pm 0.76 \mathrm{a}$ & $0.163 \pm 0.021 \mathrm{a}, \mathrm{c}$ & $0.258 \pm 0.013 \mathrm{a}$ & $0.371 \pm 0.024 \mathrm{a}$ & $115 \pm 16.6 \mathrm{~d}$ \\
\hline & Rabigato & $31.4 \pm 0.91$ b,c & $0.133 \pm 0.021 \mathrm{a}$ & $0.284 \pm 0.031 \mathrm{a}, \mathrm{b}$ & $0.385 \pm 0.049 \mathrm{a}$ & $109 \pm 6.75 \mathrm{~d}$ \\
\hline & Viosinho & $31.1 \pm 2.65 a-c$ & $0.203 \pm 0.025 c-e$ & $0.380 \pm 0.021 \mathrm{~d}, \mathrm{e}$ & $0.467 \pm 0.023 \mathrm{~b}, \mathrm{~d}$ & $84.6 \pm 15.4 \mathrm{a}-\mathrm{c}$ \\
\hline \multirow[t]{5}{*}{ Red } & Tinta Amarela & $31.8 \pm 0.63 c$ & $0.196 \pm 0.020 \mathrm{~b}-\mathrm{e}$ & $0.342 \pm 0.047 \mathrm{c}, \mathrm{d}$ & $0.420 \pm 0.028 a, b$ & $92.2 \pm 13.3 \mathrm{a}-\mathrm{d}$ \\
\hline & Tinta Roriz & $29.7 \pm 1.19 \mathrm{a}-\mathrm{c}$ & $0.234 \pm 0.007 \mathrm{e}$ & $0.376 \pm 0.045 \mathrm{~d}, \mathrm{e}$ & $0.481 \pm 0.024 \mathrm{c}, \mathrm{e}$ & $85.1 \pm 16.1 \mathrm{a}-\mathrm{c}$ \\
\hline & Touriga Franca & $28.6 \pm 1.77 \mathrm{a}-\mathrm{c}$ & $0.219 \pm 0.042 \mathrm{~d}, \mathrm{e}$ & $0.402 \pm 0.042 \mathrm{e}$ & $0.534 \pm 0.066 \mathrm{e}$ & $72.5 \pm 7.66 \mathrm{a}$ \\
\hline & Touriga Nacional & $27.5 \pm 0.26 \mathrm{a}, \mathrm{b}$ & $0.203 \pm 0.022$ c-e & $0.328 \pm 0.055 b-d$ & $0.427 \pm 0.027$ a,c & $92.7 \pm 11.7 \mathrm{a}-\mathrm{d}$ \\
\hline & $P$ value & $<0.001^{(1)}$ & $<0.001^{(1)}$ & $<0.001^{(1)}$ & $<0.001^{(1)}$ & $<0.001^{(1)}$ \\
\hline
\end{tabular}

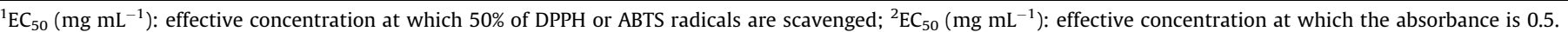

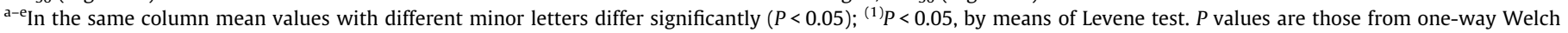
ANOVA analysis. Means were compared by Dunnett T3's test, since equal variances could not be assumed. 
under the same agricultural practices and under the same edaphoclimatic conditions. Therefore, variety explains the variability of the antioxidant properties verified in grapevine leaves. The phytochemical composition of grapevine leaves is considerably affected by the mentioned factors, changing the properties of the grapevine leaves. Therefore and based in this important aspect the phytochemical composition of the grapevine leaves varieties was studied and discussed ahead.

\subsection{Phenolic groups content}

The phenolic, flavonols and hydroxycinnamic acid derivatives contents of the ten grapevine leaf varieties are reported in Fig. 2. Total phenols content in white varieties is slightly higher than in red varieties (138 and $131 \mathrm{mg} \mathrm{GAE} \mathrm{g}^{-1}$ respectively). The same result was verified in other studies where white and red grapevine leaf varieties were compared considering their phenolic content (Fernandes et al., 2013; Koesis et al., 2015). Total phenols content varied between $112 \mathrm{mg} \mathrm{GAE} \mathrm{g}^{-1}$ (Gouveio) and $150 \mathrm{mg} \mathrm{GAE} \mathrm{g}^{-1}$ (Fernão Pires). Our results are below those presented by Fernandes et al. (2013) which reported variations between 174

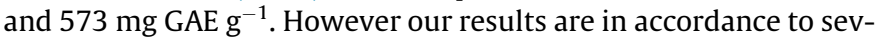
eral other grapevine leaf varieties (Andelković et al., 2015; Farhadi et al., 2016; Monagas et al., 2006).

The differences found between the study of Fernandes and collaborators and our study may reside in the edaphoclimatic conditions. Leaves from both studies were collected in different regions, with possible different edaphoclimatic conditions. For instance, the light exposure increases phenolic accumulation in leaf tissues (Koesis et al., 2015), as well as the radiation received by leaves change the phenolic content (Kolb \& Pfündel, 2005).

Regarding flavonols content and hydroxycinnamic acid derivatives they were generally quite similar among white and red varieties, 94 and $96 \mathrm{mg} \mathrm{QE} \mathrm{g}^{-1}$ for flavonols respectively, and $48 \mathrm{mg} \mathrm{CAE} \mathrm{g}^{-1}$ for hydroxycinnamic acid derivatives in both types of varieties. However, among varieties flavonols content varied between $76 \mathrm{mg} \mathrm{QE} \mathrm{g}^{-1}$ (Gouveio) and $108 \mathrm{mg} \mathrm{QE} \mathrm{g}^{-1}$ (Touriga Nacional), with significant differences among them. The same was verified for the hydroxycinnamic acid derivatives, varying between $39 \mathrm{mg} \mathrm{CAE} \mathrm{g}^{-1}$ (Gouveio) and $54 \mathrm{mg} \mathrm{CAE} \mathrm{g}^{-1}$ (Viosinho) (Fig. 2). Regarding flavonols content, our results are in accordance to those obtained in other grapevine leaf varieties (Andelković et al., 2015; Doshi, Adsule, \& Banerjee, 2006; Farhadi et al., 2016). Again, light exposure and leaves shading are very important, since strong visible light enhances the synthesis of hydroxycinnamic acids, while UV radiation has the same effect in flavonols content (Kolb et al., 2001). Therefore, part of the variances observed in our results among varieties could be attributed to the varietal effect and light exposure as well.

Correlations between the phenolic content and the antioxidant activity reported were established. For the ABTS and reducing power methods, extremely significant negative correlations were established $\left(\mathrm{R}^{2}=0.160 ; P<0.001 ; y=-1.07 \times 10^{-3} x+0.476\right.$ for ABTS; $\left.R^{2}=0.188 ; P<0.001 ; y=-1.29 \times 10^{-3} x+0.613\right)$, therefore, with a higher phenolic content, the $\mathrm{EC}_{50}$ values decrease, which means that higher antioxidant activity is displayed. No correlation was verified in the DPPH method $\left(R^{2}=0.010 ; P=0.344\right.$; $y=-1.9 \times 10^{-4} x+0.215$ ).

\subsection{Selection of grapevine leaf varieties for culinary process}

The ten varieties of grapevine leaves revealed good antioxidant properties and a rich source of phenolic compounds. At naked eye Malvasia Fina appears to be a good variety as a candidate for culinary process. Even though the data obtained in the antioxidant activity, and in the phytochemical composition was applied in a PCA to verify if new information could be retrieved for the selection of the most appropriate variety/varieties. In Fig. 3 is reported the PCA obtained with the ten grapevine leaf varieties. With only two principal components (PC's) $81.49 \%$ of the total variance could be explained [56.81\% in the first PC (PC1) and $24.68 \%$ in the second PC (PC2)]. In the positive regions of both PC's are mainly represented three varieties: Malvasia Fina, Touriga Nacional, and some samples of Fernão Pires (Fig. 3). These three varieties were mainly characterized in the PCA by a higher content in flavonols, total phenols content (TPC) and hydroxycinnamic acid derivatives (HAD). In the horizontal opposite position (negative region of PC1 and positive region of $\mathrm{PC} 2$ ) are mainly represented Touriga Franca and Tinta Roriz. These two varieties were characterized in the PCA as those with higher $\mathrm{EC}_{50}$ values in the antioxidant methods (DPPH, ABTS, and reducing power), which means that were the ones with lower antioxidant activity. Therefore, Malvasia Fina was among the varieties who reported higher antioxidant activity (Table 1).

Based on the antioxidant activity results and in the composition in total phenols, flavonols and hydroxycinnamic acid derivatives, as well as in the interpretation retrieved from the PCA, leaves from Malvasia Fina are among the most qualified candidates, among the varieties studied, to be submitted to culinary processes for human consumption.

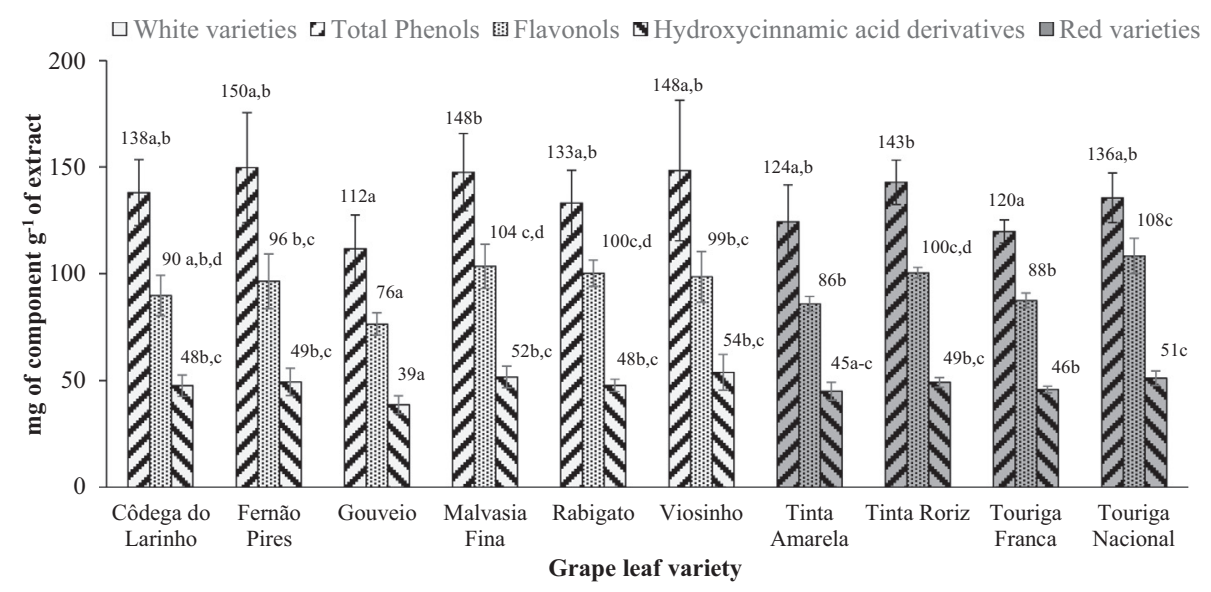

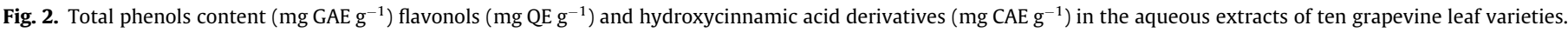
For each determination, mean values with different minor letters differ significantly $(P<0.05)$. 


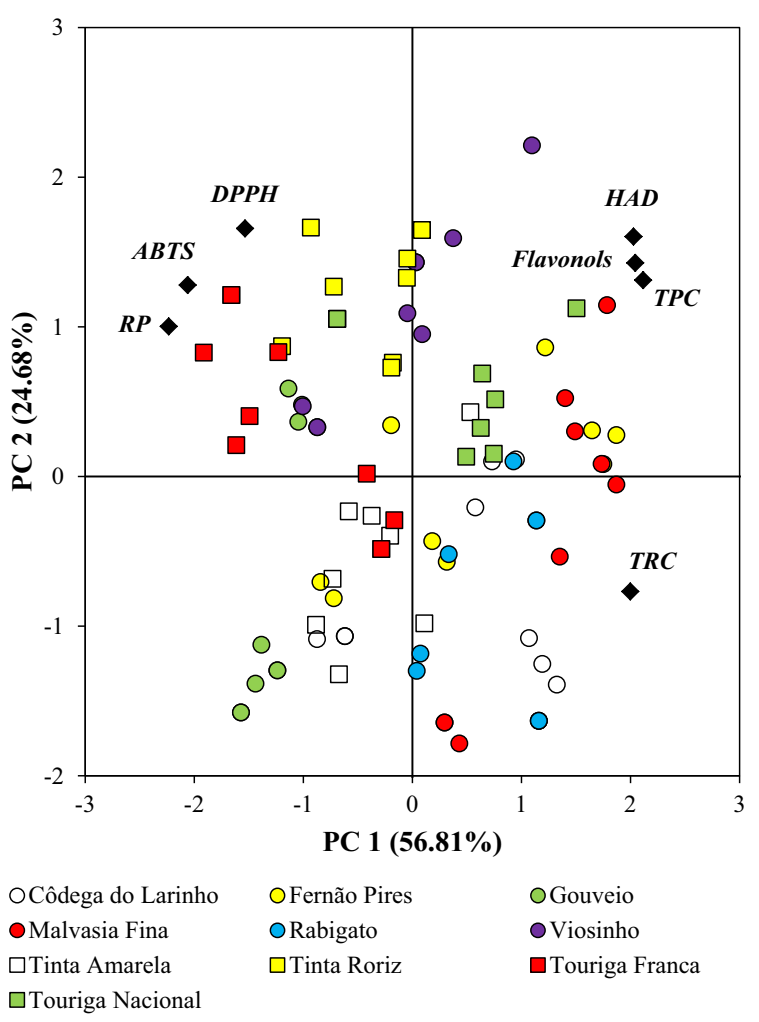

Fig. 3. Principal component analysis obtained from the ten grapevine leaf varieties by using the data relative to the antioxidant activity $\left(\mathrm{EC}_{50}\right.$ values of $\mathrm{DPPH}, \mathrm{ABTS}$ and reducing power (RP), as well as total reducing capacity (TRC)) and phenolic composition (TPC - total phenols content; HAD - hydroxycinnamic acid derivatives). The principal components explain $81.49 \%$ of the total variance.

\section{Conclusions}

The main conclusion of the present study is that the effect of variety is patent in the phytochemicals composition and in the antioxidant activity of grapevine leaves. White varieties are characterized for a general higher antioxidant activity linked to its composition in phenolic compounds. Malvasia Fina seems to be the best grapevine leaf variety to test under culinary process for the inclusion in human diet due to its high antioxidant potential and due to being rich in phenolic compounds. In the opposite position is Touriga Franca. Further studies need to be carried out with these and other varieties to verify the impact of the culinary process in the composition and nutritional value of grapevine leaves.

\section{Acknowledgements}

The authors are grateful to PRODER (Programa de Desenvolvimento Rural) for the financial support under the project "Proteção da videira contra pragas e doenças em modo de produção biológico para obtenção de vinho biológico" (n47476).

\section{References}

Aguilar, T., Loyola, C., de Bruijn, J., Bustamante, L., Vergara, C., von Baer, D., ... Serra, I. (2015). Effect of thermomaceration and enzymatic maceration on phenolic compounds of grape must enriched by grape pomace, vine leaves and canes. European Food Research and Technology. http://dx.doi.org/10.1007/s00217-0152619-3.

Andelković, M., Radovanović, B., Andelković, A. M., \& Radovanović, V. (2015). Phenolic compounds and bioactivity of healthy and infected grapevine leaf extracts from red varieties Merlot and Vranac (Vitis vinifera L.). Plant Foods for Human Nutrition, 70, 317-323.

Berker, K., Güçlü, K., Tor, I., \& Apak, R. (2007). Comparative evaluation of Fe (III) reducing power-based antioxidant capacity assays in the presence of phenanthroline, batho-phenanthroline, tripyridyltriazine (FRAP) and ferricyanide reagents. Talanta, 72, 1157-1165.

Boulanouar, B., Abdelaziz, G., Aazza, S., Gago, C., \& Miguel, M. G. (2013). Antioxidant activities of eight Algerian plant extracts and two essential oils. Industrial Crops and Products, 46, 85-96.

Doshi, P., Adsule, P., \& Banerjee, K. (2006). Phenolic composition and antioxidant activity in grapevine parts and berries (Vitis vinifera L.) cv. Kishmish Chornyi (Sharad Seedless) during maturation. International Journal of Food Science and Technology, 41, 1-9.

FAOSTAT (2015). Food and Agriculture Organization of the United Nations Statistics Division. http://faostat3.fao.org/browse/Q/QC/E. accessed 16/02/01.

Farhadi, K., Esmaeilzadeh, F., Hatami, M., Forough, M., \& Molaie, R. (2016). Determination of phenolic compounds content and antioxidant activity in skin, pulp, seed, cane and leaf of five native grape cultivars in West Azerbaijan province, Iran. Food Chemistry, 199, 847-855.

Fernandes, F., Ramalhosa, E., Pires, P., Verdial, J., Valentão, P., Andrade, P., ... Pereira, J. A. (2013). Vitis vinifera leaves towards bioactivity. Industrial Crops and Products, 43, 434-440.

Harb, J., Alseekh, S., Tohge, T., \& Fernie, A. R. (2015). Profiling of primary metabolites and flavonols in leaves of two table grape varieties collected from semiarid and temperate regions. Phytochemistry, 117, 444-455.

Hatano, T., Kagawa, H., Yasuhara, T., \& Okuda, T. (1988). Two new flavonoids and other constituents in licorice root: Their relative astringency as scavenging effects. Chemical and Pharmaceutical Bulletin, 36, 2090-2097.

Katalinić, V., Generalić, I., Skroza, D., Ljubenkov, I., Teskera, A., Konta, I., \& Boban, M. (2009). Insight in the phenolic composition and antioxidative properties of Vitis vinifera leaves extracts. Croatian Journal of Food Science and Technology, 1, 7-15.

Katalinić, V., Mozina, S. S., Generalić, I., Skroza, D., Ljubenkov, I., \& Klancnik, A. (2013). Phenolic profile, antioxidant capacity, and antimicrobial activity of leaf extracts from six Vitis vinífera L. varieties. International Journal of Food Properties, $16,45-60$.

Karaçelil, A A. Küçük, M., Iskefiyeli, Z, Aydemir, S., De Smet, S., Miserez, B., \& Sandra, P. (2015). Antioxidant components of Viburnum opulus L. determined by on-line HPLC-UV-ABTS radical scavenging and LC-UV-ESI-MS methods. Food Chemistry, 175, 106-114.

Koesis, M., Abrankó, L., Ayaydin, F., Csepregi, K., Papp, N., Teszlák, P., \& Jakab, G. (2015). Main leaf polyphenolic components of berry color variant grapevines and their acclimative responses to sunlight exposure. Applied Sciences, 5 1955-1969.

Kolb, C. A., Käser, M. A., Kopecky, J., Zotz, G., Riederer, M., \& Pfündel, E. E. (2001). Effects of natural intensities of visible and ultraviolet radiation on epidermal ultraviolet screening and photosynthesis in grape leaves. Plant Physiology, 127, 863-875.

Kolb, C. A., \& Pfündel, E. E. (2005). Origins of non-linear and dissimilar relationships between epidermal UV absorbance and UV absorbance of extracted phenolics in leaves of grapevine and barley. Plant, Cell \& Environment, 28, 580-590.

Malheiro, R., Sá, O., Pereira, E., Aguiar, C., Baptista, P., \& Pereira, J. A. (2012). Arbutus unedo L. leaves as source of phytochemicals with bioactive properties. Industrial Crops and Products, 37, 473-478.

Monagas, M., Hernández-Ledesma, B., Gómez-Cordovés, C., \& Bartolomé, B. (2006). Commercial dietary ingredients from Vitis vinifera L. leaves and grape skins: Antioxidant and chemical characterization. Journal of Agricultural and Food Chemistry, 54, 319-327.

Singleton, V. L., \& Rossi, J. R. Jr., (1965). Colorimetry of total phenolics with phosphomolybdic-phosphotungstic acid reagents. American Journal of Enology and Viticulture, 16, 144-158. 